\title{
Environmental impact of volcanic eruptions
}

\author{
SIGURDUR REYNIR GISLASON ${ }^{1}$, EYDÍS S. \\ EIRIKSDOTTIR ${ }^{2}$, IWONA M. GALECZKA ${ }^{1,3}$ \\ ${ }^{1}$ Institute of Earth Sciences, University of Iceland, 101 \\ Reykjavík, Iceland (*sigrg@hi.is) \\ ${ }^{2}$ Marine and Freshwater Research Institute, 101 Reykjavík, \\ Iceland (eydis.salome.eiriksdottir@hafogvatn.is) \\ 3̇celand Geosurvey, 108 Reykjavík, Iceland (iwona@hi.is)
}

Volcanic eruptions can have significant effects on the natural and human environments. Many volcanoes are covered with glaciers and often generate volcanic ash, gas, aerosols, lahars and occasionally, "Amazonian"-sized floods when they erupt. Pyroclastic flows can have a devastating impact on highly populated areas. The degree to which volcanic products pollute the environment and disturb air traffic, such as during the 2010 Eyjafjallajökull Iceland eruption, depends on eruption size, timing, location and international regulations. Fine-grained volcanic ash can travel for days in the air, and has a large specific surface area that is coated with acid and metal salts, which dissolve rapidly when exposed to surface waters. The ash and aerosol fallout and floods can both fertilise and pollute surface waters [1]. The 1783-84 Laki Iceland eruption produced in eight months about $14 \mathrm{~km}^{3}$ of lava and $120 \mathrm{Mt} \mathrm{SO}_{2}$, leading to the deaths of about $60 \%$ of the grazing livestock and $20 \%$ of the human population in Iceland [2]. The average monthly Laki $\mathrm{SO}_{2}$ emission rates were twice that of the combined monthly emissions from USA, Canada and Western and Central Europe during peak anthropogenic $\mathrm{SO}_{2}$ emissions in the 1970s; this had caused massive acid rain problems, mobilisation of aluminium from rocks and soil and degradation of aquatic and terrestrial ecosystems. The 178384 Bardarbunga Iceland basaltic eruption, which occurred during winter, underscored the importance of timing and location of large effusive eruptions with respect to their environmental impacts. Formation of $\mathrm{H}_{2} \mathrm{SO}_{4}$ is slow in dry weather conditions, since the oxidation of $\mathrm{SO}_{2}$ is sluggish in dry air compared to humid air. The oxidation in dry air is also minimised at high latitudes in winter, due to limited sunlight. The Laki eruption started $8^{\text {th }}$ of June 1783 , with the largest effusive rates during the first six weeks when the $\mathrm{SO}_{2}$ gas was exposed to nearly 24 hours of sunlight and minimum wind speed, maximising this eruption's environmental impact [3].

[1] Gislason, S.R. et al., 2011. PNAS 108, 7307-7312.

[2] Thordarson, T., Self, S., 2003. Journal of Geophysical Research 108, NO. D1, 4011.

[3] Gislason, S.R. et al., 2015. Geochemical Perspective Letters 1, 84-93 I doi: 10.7185/geochemlet.1509 